\title{
A study of the anatomy and physiology of nectaries: a translation of Gaston Bonnier's seminal work (1878, Bulletin de la Société Botanique de France)
}

\author{
Florian Jabbour \\ Sorbonne Universités, Paris, France

\begin{abstract}
To fuel the research on nectar and nectaries, I propose here an English translation of a seminal article published 140 years ago in the Bulletin de la Société Botanique de France, which was one of the former titles of the current Botany Letters. The reference of the original publication is: Bonnier, G. 1878. "Etude sur l'anatomie et la physiologie des nectaires." Bulletin de la Société Botanique de France 25 (8): 262-271. doi: 10.1080/00378941.1878.10827912. The translated article is preceded by an introduction clarifying the scientific context, and followed by a synthesis of subsequent
\end{abstract} \\ and recent studies about nectar and nectaries.
}

Muséum national d'Histoire naturelle, Institut de Systématique, Évolution, Biodiversité, UMR 7205 ISYEB MNHN/CNRS/UPMC/EPHE,

\section{KEYWORDS}

Extrafloral nectaries; floral nectaries; Gaston Bonnier; nectar; plant anatomy

\section{The research about nectaries and nectar}

Nectaries are structures that synthesize and secrete nectar, an energy-providing solute. In flowering plants nectaries play a major role in pollinator attraction and reward (hence for plant reproduction), and more broadly in vascular plants they are involved in plantanimal (visitors, pollinators, robbers, herbivores) interactions. Nectaries can be floral or extrafloral (Marazzi, Bronstein, and Koptur 2013); they are not found in roots (although Balendres et al. $(2016,2017)$ found root sugary exudates having an impact on biotic interactions in the rhizosphere).

Nectar production evolved at least 457 times independently in angiosperms, and the evolution of this physiological trait is characterized by repeated gains and losses (Weber and Keeler 2013). A very diverse array of floral nectaries has been described and documented in the literature (reviewed in Bernardello 2007 and Schmid 1988).

As early as in the eighteenth century, nectaries have intrigued scholars in natural history, and since then research on nectaries and nectar has been very active in the fields of histology, chemistry, physics, physiology, evo-devo and pollination ecology.

Roy et al. (2017) synthesized the landmarks in the study of nectaries and nectar (see their Table 1). Below, I add a few more points to their list, based on Bonnier's (1879) doctoral thesis.

- 1717: Sébastien Vaillant (French botanist) named "mielliers" the floral parts that produce sugary secretions. In French, "miel" means honey; "mielliers" would then mean the structure producing honey.

- 1735: Linnaeus coined the term "nectary" to designate the floral parts secreting nectar.

- Later on, confusion in defining a nectary probably originated because of the repeated attempts to assign a morphological meaning to a secretory structure. Currently, some botanists still call nectary the accessory organ or appendage of the flower not only producing but also storing nectar (e.g. a nectar spur is called a nectary in some publications).

- 1848: Johann Caspary (German botanist) considered as nectaries every portion of the plant (no matter its position on the plant) producing sugary solutes. He introduced the distinction between floral and extrafloral nectaries.

\section{Who was Gaston Bonnier?}

Gaston Bonnier was a French botanist (1853-1922, Figure $1 \mathrm{~A}$ ). In 1879, after graduating in physics, mathematics and natural sciences, he was appointed Assistant Professor at the Ecole Nationale Supérieure in Paris and had a strong influence on teaching natural sciences in France. He is mostly famous for his comprehensive and informative floras of France (and French regions), Switzerland and Belgium. He also worked in the fields of systematics, ecology, physiology and phytogeography. He was keen on producing books and manuals 
for teaching botany and natural sciences to pupils and students (Bournerias 1990). He was a member of the Société Botanique de France for 45 years (1877-1922) and was its president twice (Aymonin and KeraudrenAymonin 1990).

In 1879, he defended a thesis entitled "Les nectaires, étude critique, anatomique et physiologique" [The nectaries, a critical, anatomical and physiological study]. This was one year after the publication of the article that is hereby translated into English.

\section{Why a translation?}

The journal Botany Letters wishes to highlight articles published (often in French) in the former versions of the journal, namely Acta Botanica Gallica (1993-2015) and Bulletin de la Société Botanique de France (1854-1992). Articles to be translated and re-published are selected according to two criteria: they had a major impact on specific fields of science at the time they were published and/or they can fuel modern research by making researchers (re-)discover old, but not obsolete, findings.

This article was communicated by Gaston Bonnier to the Société Botanique de France one year after he joined the society. At that time, he was still a $\mathrm{PhD}$ candidate. This translation is published 140 years after the original publication (Bonnier 1878), which has been cited six times (Google Scholar, September 2017), exclusively by non-French researchers. It presents the main ideas developed in Bonnier's doctoral thesis (Bonnier 1879), introducing at the same time the methods and techniques to study nectaries, and investigating the physiological and ecological roles of nectaries in a systematic framework. The doctoral thesis has had a brighter citation track. It has been cited 172 times and is a reference in this field of research. It addresses the history of the research conducted on the topic, gives lexical precisions, and reports observations (Figure $1 \mathrm{~B}-\mathrm{E}$ ), experiments and analyses about nectar chemistry and the structure, anatomy, histology, physiology and function of nectaries. The work covers numerous angiosperm taxa, and all plant parts (except roots) are considered. In addition, the link with the pollinators' behaviour is considered.

My objective is to make this publication accessible to the international community of plant researchers (chemists, botanists, physiologists, ecologists, etc.), and to arouse new and additional interest in this seminal work. It is also interesting from the history of science aspect to take some time reading the report of such innovative studies that Bonnier conducted at a very early stage of his career, at a time when technical options were scarce.

Start of translation [Notes (mostly taxonomic updates) are in square brackets]

I have been studying the physiology and anatomy of nectaries for several years. I am currently synthesizing this work, and the corresponding manuscript will be organised into two parts. First, and based on experiments, I will criticize the opinions of several authors about the role of nectaries. Second, I will report a study about the anatomy and physiology of nectaries. Today, before the audience of the Société botanique de France, I will present a short summary of the second part.
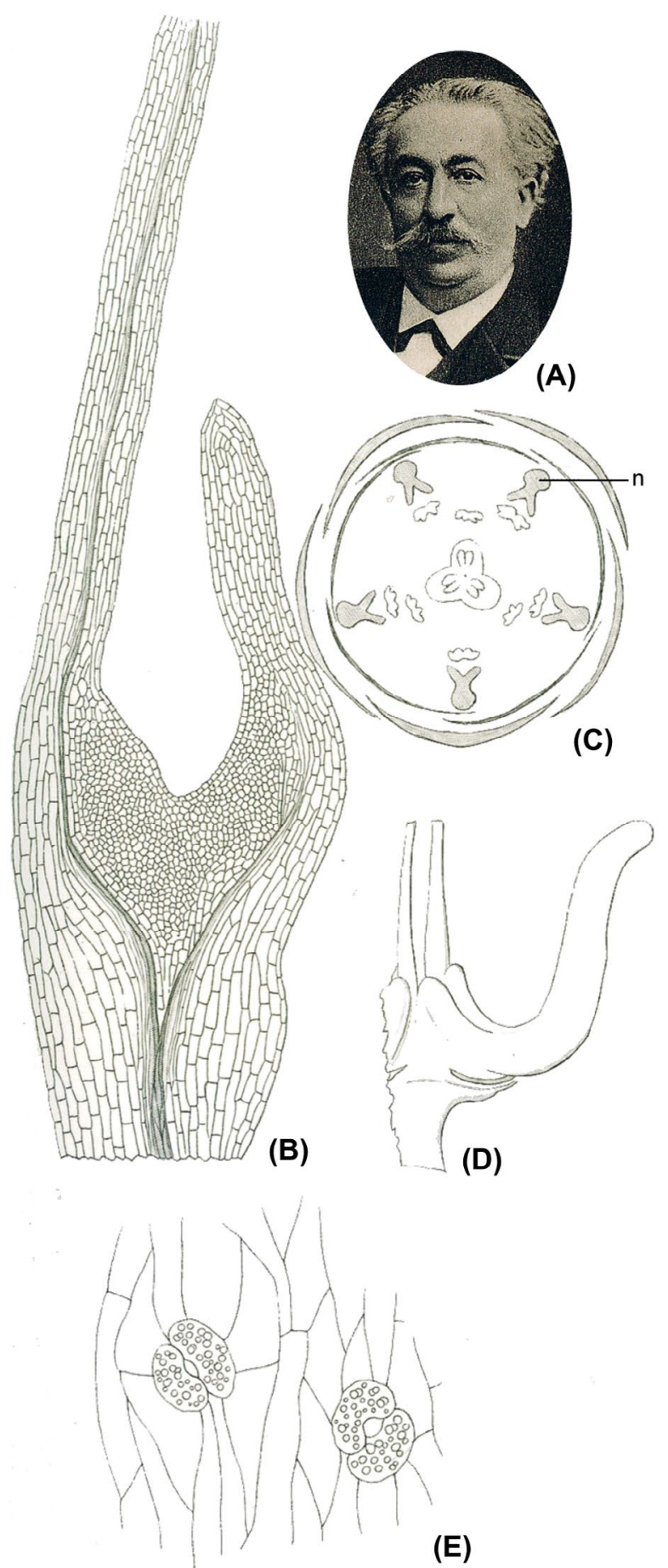

Figure 1. (A) Portrait of Gaston Bonnier, adapted from Mollier (1923), (B-E) Drawings adapted from Bonnier (1879). (B) Ranunculus acris, transverse section of a petal showing the nectariferous tissue (magnification 80x), (C) Xanthoceras sorbifolium, floral diagram, n: nectary, (D) same species, one nectary $(10 \times),(E)$ same species, stomata on the nectariferous tissue (220x). 


\section{Anatomy of nectaries}

One cannot define the morphology of nectaries. By nectary, I mean a part of the plant that is in contact with the environment and where sugary solutes accumulate, with high proportions of glucose and saccharose.

To analyse these sugars, I generally used cupropotassic tartrate and inversion using acids. In few cases, I used polarized light or fermentation.

Having studied the anatomical structure of nectaries in many genera ([footer $=] 312$ ), I can give hereby a short overview of the various characteristics of these structures.

The nectariferous tissue can be more or less differentiated. In case vascular bundles irrigate the nectariferous tissue, they can end within it, or extend beyond. The organization of xylem and phloem in a vascular bundle can be identical or opposite between the nectariferous tissue and the organ the bundle stems from.

In some cases, the vascular bundles bend inside the nectary, which then corresponds to a spur. A cross-section of this organ would then show vascular bundles with sets of xylem facing each other. The nectary can be made of a single or several appendicular organs.

The epidermis of nectaries and of neighbouring tissues is often different. In nectaries, it is smooth, covered with papillae of different shapes, and often with stomata. These stomata lack a substomatic chamber, or have a reduced substomatic chamber, filled with liquids instead of air. The stomata of nectaries are very diverse in shape. They can be sunk at the base of a funnel-shaped tissue, as in Amygdaleae [belonging in Rosaceae], or on the contrary protruding over the epidermis of the prominent parts of the nectary, as in many Papilionaceae [= subfamily Papilionoideae], or more frequently protruding among the other cells of the nectary epidermis. In few cases, the nectary epidermis is covered with a cuticle.

The parenchyma cells in which the sugary solutes accumulate are often smaller than the surrounding parenchyma cells. However, the shape and size of these two types of cells are sometimes indistinguishable, and the presence of sugar is only detected using chemical tests. These cells often contain starch grains, crystalloids, crystals, and rarely chlorophyll grains. All of these components do not characterize the nectary tissue, as they can be found in the parenchyma of other plant parts. In specific cases, the protoplasm of the nectary cells is characterized by a particular refractive power.

Sugary solutes can accumulate in diverse parts of a plant:

(1) In cotyledons. The nectariferous tissue can be observed in the embryo (Ricinus).

(2) In stipules (Vicia, Sambucus, etc.).

(3) In leaves

(a) At the base (Apocynum, Vinca, Allamanda, etc.); (b) In the petiole (Prunus, Passiflora, Cyathea, Hemithelia [Hemitelia], etc.);

(c) In the limb (Hibiscus, Crataegus, etc.);

(d) In the stipules (Sambucus ebulus).

(4) In bracts (Plumbago, etc.).

(5) In sepals:

(a) At the base (Fritillaria, Genista, etc.);

(b) On the external side (Malpighia, Hibiscus, etc.);

(c) Sepal spur (Impatiens, Tropaeolum, etc.).

(6) In petals:

(a) At the base:

(i) Vascular bundles oriented as in petals (Fritillaria imperialis, etc.);

(ii) Vascular bundles oriented in an opposite way compared with petals (Ranunculus acris, etc.);

(iii) Many vascular bundles with sets of xylem facing each other, petal base cone-shaped (Trollius, Helleborus, etc.).

(b) Petal spur (Aconitum, Aquilegia, etc.).

(7) Between sepals and stamens. Protrusions are often vascularized. The vascular bundles of the nectary originate from those of a sepal or a stamen (Cruciferae [= Brassicaceae], Geraniaceae, Xanthoceras, etc.).

(8) In stamens:

(a) In the filament (Mirabilis, Stellaria, etc.);

(b) Filament spur (Corydalis, Asclepias, etc.);

(c) Appendix of the connective (Viola).

(d) In the whole stamen (Collinsia, Anemone pulsatilla).

(9) Between stamens and carpels

(a) Between the shared base of sepals, petals, stamens, and carpels (Rosaceae, Amygdaleae, etc.);

(b) Between shared base of petals, stamens, and carpels:

(i) Particular protrusions with very differentiated vascular bundles (Vinca, Apocynum, etc.);

(ii) Small protrusions, with vascular bundles inconspicuous or absent (Gentianaceae, Daphnoïdea [Thymeleaceae], etc.);

(c) Between stamens and carpels (Papilionaceae $[=$ subfamily Papilionoideae], Ericineae, etc.).

(10) In carpels

(a) At the base. If existing, the vascular bundles are oriented as in the carpel:

(i) Protrusions opposite the carpels (Borraginaceae, Scrophulariaceae [sensu lato]);

(ii) Protrusions alternate with the carpels (Lamiaceae [as it was circumscribed in the 
pre-molecular era], Verbenaceae [as it was circumscribed in the pre-molecular era], etc.).

(b) Carpel spur (Scrophularia);

(c) At the higher part (Apiaceae, Grossulariaceae, etc.);

(d) In the parenchyma surrounding the edges of two neighbouring carpels (Liliaceae [sensu lato, as it was circumscribed in the pre-molecular era], Amaryllidaceae [sensu lato, as it was circumscribed in the pre-molecular era], etc.);

(e) At the base of the style (Asteraceae);

(f) In the stigma (Populus, Arum, etc.);

(g) On the outer part of carpels, between the vascular bundles and the outer surface (Oleaceae, Primulaceae, etc.);

(h) In the whole ovary (Ilex, Cornus, Viscum, etc.).

(11) At the shared base of all organs (Malvaceae, Caltha, Thalictrum, Tulipa, Papaver, Avena, etc.), in many instances. The accumulation of sugary solutes at the floral base is almost always linked with an accumulation of the same solutes in the floral parts as detailed here over.

According to the previous list, it appears that nectaries do not share any morphological feature, even when located in the same organ. When the nectaries consist of very different tissues, vascular bundles can be linked to one organ or another in the neighbouring plants [my interpretation: in the closest species]. In this respect, I examined 45 genera from the Brassicaceae and 20 species from the genus Geranium. The vascular bundle of the nectary can originate from the vascular bundle of a sepal or a stamen. Alternatively, it can be inserted at the exact place between the vascular bundles of the sepal and the stamen.

The vascular bundles of the nectaries show even more different organizations in closely related genera, such as in the Asclepiadaceae [= subfamily Asclepiadoideae in Apocynaceae] and Apocynaceae, etc. As a general observation, the shape and structure of floral nectaries depend on the shape and structure of the neighbouring organs. The level of differentiation of the nectary tissue seems correlated with the number of constituting cell layers on the one hand, and with the quantity of sugary solutes being accumulated on the other hand.

The development of nectaries can follow different trajectories. In some instances, only the epidermis is differentiated. However, most often the underlying tissue is also involved.

\section{Physiology of nectaries}

(1) Variation in the accumulation of sugary solutes with nectary age. No matter the nectary age, glucose is present in the nectariferous tissue in variable quantities. When the nectary is very young, it contains little or no saccharose at all. Then this sugar accumulates in variable proportions, reaches a maximum, and decreases when the nectary gets older. The peak in saccharose production seems to coincide with the secretion of sugary solutes, when this secretion occurs.

(2) Secretion of the overflow of sugary solutes. At a particular developmental stage of many nectaries, the overflow of sugary solutes can be emitted externally. Nectar secretion is a consequence of the water dissolving sugar when going through the nectariferous tissue. This exudation depends on several factors. I first studied how it operates.

Usually the liquid overflow is secreted through the stomata of the epidermis. The experimental evidence for this statement was brought in some genera. For instance, I isolated a piece of the nectary of Amygdalus persica and removed with a pipette all the nectar that was over it. The nectary was then placed between the two branches of a small clamping screw and I examined under a microscope the epidermis lit with reflected light. At low magnification, I could notice quite well the stomatal craters described above. With this experimental setting, squeezing the nectary makes droplets of nectar drip from each of the small funnels of the epidermis. No drop is produced at any other place on the epidermis. I made identical observations on many nectariferous stomata, either by proceeding as just explained, or by artificially inducing the liquid emission. I will explain below how to proceed in this latter case.

Liquid can be secreted between two disjointed cell walls without stomata (Helleborus), through the thin membranes of the epidermal cells (Fritillaria, Ranunculus, etc.), through papillae protruding from these membranes (Muscari, Ribes, etc.), through [glandular] trichomes or pluricellular hairs (Veronica, Malva, etc.), and last, due to the lifting of the cuticle and after the middle part of the cell walls has turned into mucilage (Ricinus, etc.).

However, in a fairly high number of instances, no liquid is secreted at all.

(3) Variation in the quantity of sugary solutes secreted depending on the external conditions. Before identifying the different factors that may influence the emission of sugary solutes outside the plant, I investigated the variation in nectar production in natural conditions. I summarize here my results.

Measurements were made with calibrated pipettes with a cone-shape end. The pipette diameter is designed so that all liquid is collected at the extremity of the pipette by capillarity. Plants were protected from insects with tulle stretched over wooden crates. 
Within a single species, measurements were made at the same hour of the day on a certain number of flowers with identical ages, and the mean of all observations was calculated. Flower age was determined according to the proportion of stamens with dehiscing anthers. Hygrometry and temperature in the shade and in the sun were also recorded.

(a) Variations at a single location

In 1878, at Louye (Eure [a department in the North of France]), I made three series of observations on eight species that showed different types of nectaries. Measurements were repeated every two hours for four or five consecutive days.

Results were identical for all species during sunny days with unchanging weather. Over the day, the volume of nectar secreted decreases, reaches its minimum in the early afternoon, then it increases. Generally speaking, and all other things being equal, the volumes of nectar and of the perspired water vary in opposite ways.

Two other series of observations made with diffuse light on six other plant species in the garden of the Ecole normale supérieure gave identical results.

The minimum of nectar secretion in early afternoon can be evidenced by other means. During the last two series of observations made at Louye, two hives were weighed at the exact times when measurements were made on nectaries. The weight of the hives was maximal in the afternoon, indicating that the number of bees having left the hive to collect nectar was minimal. This is easily understandable if we consider that at that time the production of nectar is minimal or even absent for some species. In the third series of observations, and to try to confirm this interpretation, we counted every two hours the number of bees staying in a hive. This number is maximal during the afternoon, at the same time when the hive's weight is also maximal.

As a last way to bring evidence to support this result, bees carrying nectar and coming back to the hive in the morning and in the afternoon were weighed. The bees captured in the afternoon are, on average, lighter than the others.

When comparing observations made at the same time during several consecutive sunny summer days, one notices that the volume of produced nectar gradually decreases. After a shower and then a sunny day, this volume increases tremendously.

(b) Variations with latitude

I made similar observations at the end of August at Domaas (Norway) and at the end of July at Louye (Eure) on the same spontaneous species. In both cases, day length was similar and measurements were made after many sunny days, in order to suppress the influence of the rain on nectar production. The volume of nectar measured at the same hour during the day on flowers of the same age and from the same species was always higher in Scandinavia than in France. It should be added that for some species, such as Potentilla tormentilla, no overflow of liquid is secreted by nectaries in France, whereas the overflow of nectar is abundant in Norway. Therefore, for the same spontaneous species, it seems that the volume of nectar secreted increases with latitude.

(c) Variations with altitude

Based on observations made in the Alps (Oisans) and in the Eastern Pyrenees in 1872 and 1873, it seems that the quantity of secreted nectar regularly increases with altitude.

In the following part, I will consider separately each of the external conditions that may influence the emission of sugary solutes.

Influence of the quantity of water absorbed by the plant. Based on the comparison of conspecific individuals whose aerial parts were in saturated air, and underground parts in contact with different quantities of water, one can conclude that:

All other things being equal, the quantity of secreted nectar increases with the quantity of water absorbed by the roots.

Influence of hygrometry. If hygrometry varies experimentally, and after measuring nectar secretion in plants whose underground parts are in totally submerged soil, one can conclude that:

All other things being equal, the quantity of secreted nectar increases with hygrometry.

It is the hygrometric state that influences nectar emission, rather than the absolute quantity of water vapour in the air.

Some plants that do not usually secrete nectar in natural conditions can artificially become nectariferous if their underground parts are placed in water and their aerial parts are placed in saturated air (Ruta, Fragaria, Tulipa, etc.).

Variation of the quantity of nectar secreted by the nectaries with the age of neighbouring organs. I measured this variation in floral nectaries at different ontogenetic stages of the flower. Floral ages were determined based on the dimension of the corolla, the state of the anthers, stigmatic papillae, and ovules, the presence of pollen tubes in the style, the occurrence of fertilization, etc. Measurements made on several species show that nectar production is maximal after the ovary has achieved its growth, and before the ovules are fertilized.

The overflow of sugary solutes is therefore mostly secreted during the ontogenetic break, when the flower does not develop anymore and before the fruit begins to develop.

Influence of the internal forces of the plant on nectar secretion. I made the following experiments on several species. 
In identical external conditions of temperature and hygrometry, I compared whole plants with roots placed in soil submerged with water, with stems cut and immersed in water, and dissected nectariferous tissue with its inferior part immersed in water. The time required for the nectaries to produce a certain volume of liquid was measured in each case.

In these experimental conditions, nectar was secreted by all nectaries, even by the dissected nectariferous tissue, but at different speed. The whole plant with vessels and roots secreted nectar faster than the cut stem [i.e. vessels only, no roots], which in turn was faster than the dissected nectariferous tissue taking water directly from its inferior part. Hence, osmotic pressure in roots and the capillarity of the vascular bundles are not essential for nectar emission, although they speed it up.

Variation in the chemical composition of exuded nectar. The secreted liquid can include polysaccharides ["gums" in the original version], albuminoids, salts, and sometimes mannitol. It always includes water, sucrose, and glucose in various proportions. The proportion of sugar in nectar varies mostly between 2/100 and $30 / 100$. Sugar can sometimes be almost absent from nectar, or conversely be the most abundant component of nectar.

The proportion of water in nectar varies a lot during the day. The analyses I conducted showed that it is at the lowest level when nectar production is minimal, which is not surprising. The nectar secreted after some rainy days contains more water than the nectar secreted after sunny days. However, water does not evaporate proportionally with the decrease in hygrometry, because the more concentrated a sugary solute is, the less efficient water evaporation is. I provided evidence for this by comparing the evaporation rate of solutions made of different sugars, honey, and nectar mixed with water in various proportions. This is partly why the non-sugary water secreted by some plants (Alchimilla, Solanum, Colocasia, etc.) evaporates much faster than the sugary liquid secreted by nectaries.

Reabsorption of sugary liquids in the plant. Reabsorption of nectar. After the nectary reaches its full development, and while it decays, the sugars accumulated partly return into the plant, no matter if an overflow of sugary liquids was secreted or not. If the nectary did not secrete its contents, due to the dissolution of sugar in the water going through this portion of the plant, then all the sugar returns into the plant.

When nectaries are located in the flower, sugary solutes are probably always transferred into the developing fruit. When nectaries are extrafloral, sugary solutes are mostly transferred to the organ at the base of which the nectaries are usually located. The transfer of sugary solutes to other organs is accompanied by a modification of their chemical nature. The non-assimilable saccharose is converted into assimilable glucose and levulose. When the secreted nectar remains in contact with the nectary, it can even be reabsorbed, as observed in several instances.

The following conclusions are made based on the experiments and observations reported above.

Sugary solutes generally accumulate in plants in the vicinity of developing organs (leaf, stipule), or of organs that will considerably develop later on (ovary).

An overflow of secreted sugary solutes generally indicates that the development of neighbouring organs has stopped or has slowed down.

When the secretion of sugary solutes ceases, the sugary portion of the nectar returns into the plant and is most likely used by the developing neighbouring parts.

In summary, nectaries can be floral or extrafloral, secreting, or not, liquid outside of the plant. In all these cases, their function of storing nutrients is in tight relation with the life of the plant.

Mister Prillieux asks whether nectaries are always covered with a cuticle, always have stomata, and whether nectar composition varies according to the time of the day.

Mister Bonnier answers that nectaries do not always have a cuticle, that stomata are often lacking, and that when the volume of nectar decreases, its density and sugar rate increase.

\section{Subsequent and recent studies about nectar and nectaries}

Building on the observations and experiments from the eighteenth and nineteenth centuries (such as those reported in Bonnier [1878]), and thanks to inputs from the fields of chemistry, physics, and microscopy, our understanding of nectary structure and physiology has largely improved. Nectary features (presence/absence, structure) are still used in some studies as taxonomically discriminant traits (see Table 1). In other studies, the now well-resolved phylogenetic relationships among angiosperms are used as a framework to unravel and interpret the evolution of nectary traits at large taxonomic scales (see Table 1). In the last years, the evo-devo of nectary development, the regulation of nectar production, and the ecological role of nectaries have become promising fields of research.

Whilst much progress has been made since Bonnier's article in 1878, it is important to keep in mind that largescale (taxonomically speaking) studies and precise and accurate observations are often reported in the old literature and ought not be overlooked. 
Table 1. One hundred articles reporting studies about nectaries and nectar, and classified into ten topics. See Roy et al. (2017, 290 citations) for a more exhaustive review of the literature.

\begin{tabular}{|c|c|}
\hline Features of nectar/-ies & Selected publications \\
\hline Structure / Development & $\begin{array}{l}\text { Fahn 1952, 1953; Frey-Wyssling 1955; Rao 1967; Findlay and Mercer 1971; Elias 1972; Rachmilevitz and Fahn } \\
\text { 1973; Wergin et al. 1975; Elias and Gelband 1976; Schnepf and Pross 1976; Baker, Hall, and Thorpe 1978; } \\
\text { Fahn 1979; Fahn and Benouaiche 1979; Teuber et al. 1980; Durkee, Gaal, and Reisner 1981; Subramanian } \\
\text { and Inamdar 1985; Davis, Peterson, and Shuel 1986, 1988; Fahn 1988; Ronse Decraene and Smets 1991; } \\
\text { Sawidis 1991; Zer and Fahn 1992; Simpson 1993; Nepi, Ciampolini, and Pacini 1996; Davis et al. 1998; } \\
\text { Gaffal, Heimler, and El-Gammal 1998; Razem and Davis 1999; Vesprini, Nepi, and Pacini 1999; Stpiczyńska } \\
\text { and Matusiewicz 2001; Horner et al. 2003; Papp 2004; Espolador Leitão et al. 2005; Stpiczyńska et al. 2005; } \\
\text { Nepi 2007; Weryszko-Chmielewska, Chwil, and Michonska 2007; Coutinho, Valente, and Meira 2010; Deroin } \\
\text { 2014; Zini, Solís, and Ferrucci 2014; Antoń and Kamińska 2015; Deroin et al. 2015; Nikolic et al. } 2015\end{array}$ \\
\hline Focus on floral nectaries & $\begin{array}{l}\text { Elias and Gelband 1976; Schnepf and Pross 1976; Fahn and Benouaiche 1979; Teuber et al. 1980; Durkee, } \\
\text { Gaal, and Reisner 1981; Davis, Peterson, and Shuel 1986, 1988; Ronse Decraene and Smets 1991; Zer and } \\
\text { Fahn 1992; Nepi, Ciampolini, and Pacini 1996; Davis et al. 1998; Gaffal, Heimler, and El-Gammal 1998; } \\
\text { Razem and Davis 1999; Stpiczyńska and Matusiewicz 2001; Horner et al. 2003; Galetto and Bernardello } \\
\text { 2004; Espolador Leitão et al. 2005; Stpiczyńska et al. 2005; Weryszko-Chmielewska, Chwil, and Michonska } \\
\text { 2007; Deroin 2014; Deroin et al. } 2015\end{array}$ \\
\hline Focus on extrafloral nectaries & $\begin{array}{l}\text { Salisbury 1909; Elias 1972; Wergin et al. 1975; Elias and Gelband 1976; Keeler 1977; Baker, Hall, and Thorpe } \\
\text { 1978; Durkee 1982; Guédès 1984; Davis, Peterson, and Shuel 1988; Heil et al. 2000; Espolador Leitão et al. } \\
\text { 2005; Coutinho, Valente, and Meira 2010; Villamil, Márquez-Guzmán, and Boege } 2013\end{array}$ \\
\hline Nectar production and secretion & $\begin{array}{l}\text { Raw 1953; Fahn 1979; Pleasants 1983; Burquez and Corbet 1991; Pyke 1991; Davis et al. 1998; Vesprini, Nepi, } \\
\text { and Pacini 1999; Heil et al. 2000; De la Barrera and Nobel 2004; Galetto and Bernardello 2004; Pacini and } \\
\text { Nepi 2007; Lüttge 2013; Villamil, Márquez-Guzmán, and Boege 2013; Antoń and Denisow 2014; Villamil } \\
2017\end{array}$ \\
\hline Nectar chemical composition & $\begin{array}{l}\text { Wykes 1952; Percival 1961; Baker and Baker 1973, 1975; Bolten and Feinsinger 1978; Bolten et al. 1979; } \\
\text { Gottsberger, Schrauwen, and Linskens 1984; Baker and Baker 1990; Davis et al. 1998; Vesprini, Nepi, and } \\
\text { Pacini 1999; Galetto and Bernardello 2004; Nicolson and Thornburg 2007; Antoń and Denisow } 2014\end{array}$ \\
\hline Interaction with animals & $\begin{array}{l}\text { Baker and Baker 1973, 1975; Bolten and Feinsinger 1978; Tilman 1978; Zimmerman 1988; Baker and Baker } \\
\text { 1990; Thorp et al. 1975; Adler 2001; Adler and Irwin 2005; Villamil, Márquez-Guzmán, and Boege 2013; Zhu } \\
\text { et al. } 2017\end{array}$ \\
\hline Evo-devo of nectary development & $\begin{array}{l}\text { Bowman and Smyth 1999; Baum, Eshed, and Bowman 2001; Lee et al. 2005; Kram and Carter 2009; Kram, Xu, } \\
\text { and Carter } 2009\end{array}$ \\
\hline Origin, diversity, and evolution & $\begin{array}{l}\text { Brown 1938; Fahn 1953; Gottsberger, Schrauwen, and Linskens 1984; Smets et al. 2000; Rudall 2002; Rudall, } \\
\text { Manning, and Goldblatt 2003; Sajo, Rudall, and Prychid 2004; De la Barrera and Nobel } 2004\end{array}$ \\
\hline $\begin{array}{l}\text { Systematics-oriented interpretation of } \\
\text { nectaries }\end{array}$ & $\begin{array}{l}\text { Norris 1941; Schmid 1985; Smets 1986; Stein and Tobe 1989; Simpson 1993; Chesselet, Smith, and van Wyk } \\
\text { 2002; Erbar and Leins 2010, 2013; Erbar 2014; Nikolic et al. } 2015\end{array}$ \\
\hline General articles & $\begin{array}{l}\text { Schmid 1988; Vogel 1997, 1998a, 1998b, 1998c; Pacini, Nepi, and Vesprini 2003; Bernardello 2007; Heil 2011; } \\
\text { Roy et al. } 2017\end{array}$ \\
\hline
\end{tabular}

\section{Acknowledgments}

I thank Sophie Nadot and Elisabeth Dodinet (Editors-inChief of Botany Letters) for having encouraged me to write this article. I am also grateful to Sophie Nadot for her comments on the manuscript.

\section{Disclosure statement}

No potential conflict of interest was reported by the author.

\section{Notes on contributor}

Florian Jabbour is an Assistant Professor at the Muséum national d'Histoire Naturelle and a curator at Paris Herbarium. His research focuses on the evolution of plant taxa and plant shapes. He is editor for Botany Letters.

\section{References}

Adler, L. S. 2001. "The Ecological Significance of Toxic Nectar." Oikos 91 (3): 409-420.

Adler, L. S., and R. E. Irwin. 2005. "Ecological Costs and Benefits of Defenses in Nectar." Ecology 86 (11): 29682978. doi:10.1890/05-0118.

Antoń, S., and B. Denisow. 2014. "Nectar Production and Carbohydrate Composition across Floral Sexual Phases: Contrasting Patterns in Two Protandrous Aconitum Species (Delphinieae, Ranunculaceae)." Flora-Morphology,
Distribution, Functional Ecology of Plants 209 (9): 464-470. doi:10.1016/j.flora.2014.07.001.

Antoń, S., and M. Kamińska. 2015. “Comparative Floral Spur Anatomy and Nectar Secretion in Four Representatives of Ranunculaceae." Protoplasma 252 (6): 1587-1601. doi:10.1007/s00709-015-0794-5.

Aymonin, G. G., and M. Keraudren-Aymonin. 1990. “Autour de Gaston Bonnier et de son œuvre. Essai documentaire comparatif." [About Gaston Bonnier's Life and Works.] Bulletin de la Société Botanique de France Lettres Botaniques 137 (2-3): 125-138. doi:10.1080/01811797. 1990.10824874.

Baker, H. G., and I. Baker. 1973. "Amino-Acids in Nectar and Their Evolutionary Significance." Nature 241 (5391): 543-545. doi:10.1038/241543b0.

Baker, H. G., and I. Baker. 1975. "Studies of NectarConstitution and Pollinator-Plant Coevolution." Coevolution of Animals and Plants 100 (140): 591-600.

Baker, H. G., and I. Baker. 1990. "The Predictive Value of Nectar Chemistry to the Recognition of Pollinator Types." Israel Journal of Botany 39 (1-2): 157-166.

Baker, D. A., J. L. Hall, and J. R. Thorpe. 1978. "A Study of the Extrafloral Nectaries of Ricinus communis." New Phytologist 81 (1): 129-137. doi:10.1111/j.1469-8137.1978. tb01612.x.

Balendres, M. A., D. S. Nichols, R. S. Tegg, and C. R. Wilson. 2016. "Metabolomes of Potato Root Exudates: Compounds That Stimulate Resting Spore Germination of the SoilBorne Pathogen Spongospora subterranea." Journal of Agricultural and Food Chemistry 64 (40): 7466-7474. doi:10.1021/acs.jafc.6b03904. 
Balendres, M. A., D. S. Nichols, R. S. Tegg, and C. R. Wilson. 2017. "Potato Root Exudation and Release of Spongospora subterranea Resting Spore Germination Stimulants Are Affected by Plant and Environmental Conditions." Journal of Phytopathology 165 (1): 64-72. doi:10.1111/ jph.12537.

Baum, S. F., Y. Eshed, and J. L. Bowman. 2001. "The Arabidopsis Nectary is an ABC-Independent Floral Structure." Development 128 (22): 4657-4667.

Bernardello, G. 2007. "A Systematic Survey of Floral Nectaries." In Nectaries and Nectar, edited by S. W. Nicolson, M. Nepi and E. Pacini, 19-128. Netherlands: Springer.

Bolten, A. B., and P. Feinsinger. 1978. "Why Do Hummingbird Flowers Secrete Dilute Nectar?” Biotropica 10 (4): 307-309.

Bolten, A. B., P. Feinsinger, H. G. Baker, and I. Baker. 1979. "On the Calculation of Sugar Concentration in Flower Nectar." Oecologia 41 (3): 301-304.

Bonnier, M. Gaston 1878. "Etude sur l'anatomie et la physiologie des nectaires." [A Study of the Anatomy and Physiology of Nectaries.] Bulletin de la Société Botanique de France 25 (8): 262-271. doi:10.1080/00378941.1878.10 827912.

Bonnier, G. 1879. Les nectaires : étude critique, anatomique et physiologique [The Nectarie: A Critical, Anatomical and Physiological Study]. Paris: G. Masson.

Bournerias, M. 1990. "Gaston Bonnier, éminent pédagogue et botaniste de terrain." [Gaston Bonnier, A Proeminent Pedagogue and Field Botanist.] Bulletin de la Société Botanique de France Lettres Botaniques 137 (2-3): 93-105. doi:10.1080/01811797.1990.10824870.

Bowman, J. L., and D. R. Smyth. 1999. "CRABS CLAW, a Gene That Regulates Carpel and Nectary Development in Arabidopsis, Encodes a Novel Protein with Zinc Finger and Helix-Loop-Helix Domains." Development 126 (11): 2387-2396.

Brown, W. H. 1938. "The Bearing of Nectaries on the Phylogeny of Flowering Plants." Proceedings of the American Philosophical Society 79 (4): 549-595.

Burquez, A., and S. A. Corbet. 1991. "Do Flowers Reabsorb Nectar?" Functional Ecology 5 (3): 369-379. doi: $10.2307 / 2389808$.

Chesselet, P., G. F. Smith, and A. E. van Wyk. 2002. "A New Tribal Classification of Mesembryanthemaceae: Evidence from Floral Nectaries." Taxon 51 (2): 295-308. doi:10.2307/1554928.

Coutinho, Í. A. C., V. M. M. Valente, and R. M. S. A. Meira. 2010. "Ontogenetic, Anatomical and Histochemical Study of the Extrafloral Nectaries of Sapium biglandulosum (Euphorbiaceae)." Australian Journal of Botany 58 (3): 224-232. doi:10.1071/BT09200.

Davis, A. R., R. L. Peterson, and R. W. Shuel. 1986. "Anatomy and Vasculature of the Floral Nectaries of Brassica napus (Brassicaceae)." Canadian Journal of Botany 64 (11): 25082516. doi:10.1139/b86-333.

Davis, A. R., R. L. Peterson, and R. W. Shuel. 1988. "Vasculature and Ultrastructure of the Floral and Stipular Nectaries of Vicia faba (Leguminosae)." Canadian Journal of Botany 66 (7): 1435-1448. doi:10.1139/b88-198.

Davis, A. R., J. D. Pylatuik, J. C. Paradis, and N. H. Low. 1998. "Nectar-Carbohydrate Production and Composition Vary in Relation to Nectary Anatomy and Location within Individual Flowers of Several Species of Brassicaceae." Planta 205 (2): 305-318. doi:10.1007/s004250050325.

De la Barrera, E., and P. S. Nobel. 2004. "Nectar: Properties, Floral Aspects, and Speculations on Origin." Trends in Plant Science 9 (2): 65-69. doi:10.1016/j.tplants.2003.12.003.
Deroin, T. 2014. "Vascular Anatomy of the Flower of Hyacinthoides non-scripta (L.) Chouard Ex Rothm. a New Insight about a Complex Placentation Pattern in Asparagaceae." Modern Phytomorphology 5: 9-18.

Deroin, T., C. Damerval, M. Le Guilloux, and F. Jabbour. 2015. "Floral Vascular Patterns of the Double-Flowered and Wild-Type Morphs of Nigella damascena L. (Ranunculaceae)." Modern Phytomorphology 7: 13-20.

Durkee, L. T. 1982. "The Floral and Extra-Floral Nectaries of Passiflora. II. The Extra-Floral Nectary." American Journal of Botany 69 (9): 1420-1428.

Durkee, L. T., D. J. Gaal, and W. H. Reisner. 1981. “The Floral and Extra-Floral Nectaries of Passiflora. I. The Floral Nectary." American Journal of Botany 68 (4): 453-462.

Elias, T. S. 1972. "Morphology and Anatomy of Foliar Nectaries of Pithecellobium macradenium (Leguminosae)." Botanical Gazette 133 (1): 38-42.

Elias, T. S., and H. Gelband. 1976. "Morphology and Anatomy of Floral and Extrafloral Nectaries in Campsis (Bignoniaceae)." American Journal of Botany 63 (10): 1349-1353.

Erbar, C. 2014. "Nectar Secretion and Nectaries in Basal Angiosperms, Magnoliids and Non-Core Eudicots and a Comparison with Core Eudicots." Plant Diversity and Evolution 131 (2): 63-143. doi:10.1127/18696155/2014/0131-0075.

Erbar, C., and P. Leins. 2010. "Nectaries in Apiales and Related Groups." Plant Diversity and Evolution 128 (1): 269-295. doi:10.1127/1869-6155/2010/0128-0013.

Erbar, C., and P. Leins. 2013. "Nectar Production in the Pollen Flower of Anemone nemorosa in Comparison with Other Ranunculaceae and Magnolia (Magnoliaceae)." Organisms Diversity \& Evolution 13 (3): 287-300. doi:10.1007/ s13127-013-0131-9.

Espolador Leitão, C. A., R. M. Strozi Alves Meira, A. A. Azevedo, J. M. de Araújo, K. L. F. Silva, and R. G. Collevatti. 2005. "Anatomy of the Floral, Bract, and Foliar Nectaries of Triumfetta semitriloba (Tiliaceae)." Canadian Journal of Botany 83 (3): 279-286. doi:10.1139/b05-001.

Fahn, A. 1952. "On the Structure of Floral Nectaries." Botanical Gazette 113 (4): 464-470.

Fahn, A. 1953. "The Topography of the Nectary in the Flower and Its Phylogenetical Trend." Phytomorphology 3: 424426.

Fahn, A. 1979. "Ultrastructure of Nectaries in Relation to Nectar Secretion." American Journal of Botany 66 (8): 977-985.

Fahn, A. 1988. "Secretory Tissues in Vascular Plants." New Phytologist 108(3):229-257.doi:10.1111/j.1469-8137.1988. tb04159.x.

Fahn, A., and P. Benouaiche. 1979. "Ultrastructure, Development and Secretion in the Nectary of Banana Flowers." Annals of Botany 44 (1): 85-93. doi:10.1093/ oxfordjournals.aob.a085710.

Findlay, N., and F. V. Mercer. 1971. "Nectar Production in Abutilon II. Submicroscopic Structure of the Nectary." Australian Journal of Biological Sciences 24 (3): 657-664. doi:10.1071/BI9710657.

Frey-Wyssling, A. 1955. "The Phloem Supply to the Nectaries." Acta Botanica Neerlandica 4 (3): 358-369. doi:10.1111/j.1438-8677.1955.tb00337.x.

Gaffal, K. P., W. Heimler, and S. El-Gammal. 1998. "The Floral Nectary of Digitalis purpurea L., Structure and Nectar Secretion." Annals of Botany 81 (2): 251-262.

Galetto, L., and G. Bernardello. 2004. "Floral Nectaries, Nectar Production Dynamics and Chemical Composition in Six Ipomoea Species (Convolvulaceae) in Relation to 
Pollinators." Annals of Botany 94 (2):269-280. doi:10.1093/ aob/mch137.

Gottsberger, G., J. Schrauwen, and H. F. Linskens. 1984. "Amino Acids and Sugars in Nectar, and Their Putative Evolutionary Significance." Plant Systematics and Evolution 145 (1-2): 55-77. doi:10.1007/BF00984031.

Guédès, M. 1984. "Leaf Morphology in Ricinus: Meaning of Extrafloral Nectaries." Phytomorphology 34 (1-4): 147157.

Heil, M. 2011. "Nectar: Generation, Regulation and Ecological Functions." Trends in Plant Science 16 (4): 191200. doi:10.1016/j.tplants.2011.01.003.

Heil, M., B. Fiala, B. Baumann, and K. E. Linsenmair. 2000. "Temporal, Spatial and Biotic Variations in Extrafloral Nectar Secretion by Macaranga tanarius." Functional Ecology 14 (6): 749-757. doi:10.1046/j.13652435.2000.00480.x.

Horner, H. T., R. A. Healy, T. Cervantes-Martinez, and R. G. Palmer. 2003. "Floral Nectary Fine Structure and Development in Glycine max L. (Fabaceae)." International Journal of Plant Sciences 164 (5): 675-690. doi:10.1086/377060.

Keeler, K. H. 1977. "The Extrafloral Nectaries of Ipomoea carnea (Convolvulaceae)." American Journal of Botany 64 (10): 1182-1188. doi:10.2307/2442480.

Kram, B. W., and C. J. Carter. 2009. "Arabidopsis thaliana as a Model for Functional Nectary Analysis." Sexual Plant Reproduction 22 (4): 235-246. doi:10.1007/s00497-0090112-5.

Kram, B. W., W. W. Xu, and C. J. Carter. 2009. “Uncovering the Arabidopsis thaliana Nectary Transcriptome: Investigation of Differential Gene Expression in Floral Nectariferous Tissues.” BMC Plant Biology 9 (1): 92. doi:10.1186/14712229-9-92.

Lee, J. Y., S. F. Baum, S. H. Oh, C. Z. Jiang, J. C. Chen, and J. L. Bowman. 2005. "Recruitment of CRABS CLAW to Promote Nectary Development within the Eudicot Clade." Development 132 (22): 5021-5032. doi:10.1242/ dev.02067.

Lüttge, U. 2013. "Green Nectaries: The Role of Photosynthesis in Secretion." Botanical Journal of the Linnean Society 173 (1): 1-11. doi:10.1111/boj.12066.

Marazzi, B., J. L. Bronstein, and S. Koptur. 2013. "The Diversity, Ecology and Evolution of Extrafloral Nectaries: Current Perspectives and Future Challenges." Annals of Botany 111 (6): 1243-1250. doi:10.1093/aob/mct109.

Mollier, M. 1923. Notice sur la vie et les travaux de Gaston Bonnier. Paris: Gauthier-Villars et Cie.

Nepi, M. 2007. "Nectary Structure and Ultrastructure." In Nectaries and Nectar, edited by S. W. Nicolson, M. Nepi and E. Pacini, 129-166. Netherlands: Springer.

Nepi, M., F. Ciampolini, and E. Pacini. 1996. "Development and Ultrastructure of Cucurbita pepo Nectaries of Male Flowers." Annals of Botany 78 (1): 95-104. doi:10.1006/ anbo.1996.0100.

Nicolson, S. W., and R. W. Thornburg. 2007. "Nectar Chemistry." In Nectaries and Nectar, edited by S. W. Nicolson, M. Nepi and E. Pacini, 215-264. Netherlands: Springer.

Nikolic, D., M. Spasic, J. Sinzar-Sekulic, V. Randjelovic, and D. Lakusic. 2015. "Morphometric Analysis of Nectaries and Their Potential Use in the Taxonomy of the Jovibarba heuffelii Complex (Crassulaceae)." Archives of Biological Sciences 67 (2): 511-524. doi:10.2298/ABS140911014 N.

Norris, T. 1941. "Torus Anatomy and Nectary Characteristics as Phylogenetic Criteria in the Rhoeadales." American Journal of Botany 28 (2): 101-113.
Pacini, E., and M. Nepi. 2007. "Nectar Production and Presentation." In Nectaries and Nectar, edited by S. W. Nicolson, M. Nepi and E. Pacini, 167-214. Netherlands: Springer.

Pacini, E., M. Nepi, and J. L. Vesprini. 2003. "Nectar Biodiversity: A Short Review." Plant Systematics and Evolution 238 (1-4): 7-21. doi:10.1007/s00606-002-0277-y.

Papp, N. 2004. "Nectar and Nectary Studies on Seven Euphorbia Species." Acta Botanica Hungarica 46 (1-2): 225-234. doi:10.1556/ABot.46.2004.1-2.16.

Percival, M. S. 1961. "Types of Nectar in Angiosperms.” New Phytologist 60 (3): 235-281. doi:10.1111/j.1469-8137.1961. tb06255.x.

Pleasants, J. M. 1983. "Nectar Production Patterns in Ipomopsis aggregata (Polemoniaceae)." American Journal of Botany 70 (10): 1468-1475.

Pyke, G. H. 1991. "What Does It Cost a Plant to Produce Floral Nectar?” Nature 350 (6313): 58-59. doi:10.1038/350058a0.

Rachmilevitz, T., and A. Fahn. 1973. "Ultrastructure of Nectaries of Vinca rosea L., Vinca major L. and Citrus sinensis Osbeck cv. Valencia and Its Relation to the Mechanism of Nectar Secretion." Annals of Botany 37 (1): 1-9. doi:10.1093/oxfordjournals.aob.a084662.

Rao, C. V. 1967. "Morphology of the Nectary in Proteaceae." New Phytologist 66 (1): 99-107.

Raw, G. R. 1953. “The Effect on Nectar Secretion of Removing Nectar from Flowers." Bee World 34 (2): 23-25. doi:10.108 0/0005772X.1953.11094777.

Razem, F. A., and A. R. Davis. 1999. "Anatomical and Ultrastructural Changes of the Floral Nectary of Pisum sativum L. during Flower Development." Protoplasma 206 (1-3): 57-72. doi:10.1007/BF01279253.

Ronse Decraene, L. P., and E. Smets. 1991. "Androecium and Floral Nectaries of Harungana madagascariensis (Clusiaceae)." Plant Systematics and Evolution 178 (3-4): 179-194. doi:10.1007/BF00937963.

Roy, R., A. J. Schmitt, J. B. Thomas, and C. J. Carter. 2017. "Nectar Biology: From Molecules to Ecosystems." Plant Science 262: 148-164. doi:10.1016/j.plantsci.2017.04.012.

Rudall, P. 2002. "Homologies of Inferior Ovaries and Septal Nectaries in Monocotyledons." International Journal of Plant Sciences 163 (2): 261-276. doi:10.1086/338323.

Rudall, P. J., J. C. Manning, and P. Goldblatt. 2003. "Evolution of Floral Nectaries in Iridaceae." Annals of the Missouri Botanical Garden 90 (4): 613-631. doi:10.2307/3298546.

Sajo, M. G., P. J. Rudall, and C. J. Prychid. 2004. "Floral Anatomy of Bromeliaceae, with Particular Reference to the Evolution of Epigyny and Septal Nectaries in Commelinid Monocots." Plant Systematics and Evolution 247 (3-4): 215-231. doi:10.1007/s00606-002-0143-0.

Salisbury, E. J. 1909. "The Extra-Floral Nectaries of the Genus Polygonum.” Annals of Botany os-23 (2): 229-242. doi:10.1093/oxfordjournals.aob.a089212.

Sawidis, T. 1991. "A Histochemical Study of Nectaries of Hibiscus rosa-sinensis." Journal of Experimental Botany 42 (11): 1477-1485. doi:10.1093/jxb/42.11.1477.

Schmid, R. 1985. "Functional Interpretations of the Morphology and Anatomy of Septal Nectaries." Acta Botanica Neerlandica 34 (1): 125-128. doi:10.1111/j.1438-8677.1985.tb01862.x.

Schmid, R. 1988. "Reproductive versus Extra-Reproductive Nectaries - Historical Perspective and Terminological Recommendations." The Botanical Review 54 (2): 179-227.

Schnepf, E., and E. Pross. 1976. "Differentiation and Redifferentiation of a Transfer Cell: Development of Septal Nectaries of Aloe and Gasteria." Protoplasma 89 (1-2): 105-115. doi:10.1007/BF01279332. 
Simpson, M. G. 1993. "Septal Nectary Anatomy and Phylogeny of the Haemodoraceae." Systematic Botany 18 (4): 593-613. doi:10.2307/2419536.

Smets, E. 1986. "Localization and Systematic Importance of the Floral Nectaries in the Magnoliatae (Dicotyledons)." Bulletin du Jardin Botanique National de Belgique/Bulletin van de Nationale Plantentuin van Belgie 56 (1/2): 51-76. doi: $10.2307 / 3667757$.

Smets, E. F., L. P. Ronse Decraene, P. Caris, and P. J. Rudall. 2000. "Floral Nectaries in Monocotyledons: Distribution and Evolution." In Monocots: Systematics and Evolution, edited by K. L. Wilson and D. Morrison, 230-240. Sydney: CSIRO Publishing.

Stein, B. A., and H. Tobe. 1989. "Floral Nectaries in Melastomataceae and Their Systematic and Evolutionary Implications." Annals of the Missouri Botanical Garden 76 (2): 519-531. doi:10.2307/2399498.

Stpiczyńska, M., and J. Matusiewicz. 2001. "Anatomy and Ultrastructure of Spur Nectary of Gymnadenia conopsea (L.) Orchidaceae." Acta Societatis Botanicorum Poloniae 70 (4): 267-272. doi:10.5586/asbp.2001.034.

Stpiczyńska, M., C. Milanesi, C. Faleri, and M. Cresti. 2005. "Ultrastructure of the Nectary Spur of Platanthera chlorantha (Custer) Rchb. (Orchidaceae) during Successive Stages of Nectar Secretion." Acta Biologica Cracoviensia Series Botanica 47 (2): 111-119.

Subramanian, R. B., and J. A. Inamdar. 1985. "Occurrence, Structure, Ontogeny and Biology of Nectaries in Kigelia pinnata DC." Journal of Plant Research 98 (1): 67-73. doi:10.1007/BF02488907.

Teuber, L. R., M. C. Albertsen, D. K. Barnes, and G. H. Heichel. 1980. "Structure of Floral Nectaries of Alfalfa (Medicago sativa L.) in Relation to Nectar Production." American Journal of Botany 67 (4): 433-439.

Thorp, R. W., D. L. Briggs, J. R. Estes, and E. H. Erickson. 1975. "Nectar Fluorescence under Ultraviolet Irradiation.” Science 189 (4201): 476-478. doi:10.1126/ science.189.4201.476.

Tilman, D. 1978. "Cherries, Ants and Tent Caterpillars: Timing of Nectar Production in Relation to Susceptibility of Caterpillars to Ant Predation." Ecology 59 (4): 686-692. doi:10.2307/1938771.

Vesprini, J. L., M. Nepi, and E. Pacini. 1999. "Nectary Structure, Nectar Secretion Patterns and Nectar Composition in Two Helleborus Species." Plant Biology 1 (5): 560-568. doi:10.1111/j.1438-8677.1999.tb00784.x.

Villamil, N. 2017. "Why Are Flowers Sweeter than Fruits or Buds? Variation in Extrafloral Nectar Secretion throughout the Floral Ontogeny of a Myrmecophile." Biotropica 49 (5): 581-585. doi:10.1111/btp.12463.

Villamil, N., J. Márquez-Guzmán, and K. Boege. 2013. "Understanding Ontogenetic Trajectories of Indirect
Defence: Ecological and Anatomical Constraints in the Production of Extrafloral Nectaries." Annals of Botany 112 (4): 701-709. doi:10.1093/aob/mct005.

Vogel, S. 1997. "Remarkable Nectaries: Structure, Ecology, Organophyletic Perspectives I. Substitutive Nectaries." Flora 192 (4): 305-333. doi:10.1016/S0367-2530(17)30798-3.

Vogel, S. 1998a. "Remarkable Nectaries: Structure, Ecology, Organophyletic Perspectives: II. Nectarioles.” Flora 193 (1): 1-29. doi:10.1016/S0367-2530(17)30812-5.

Vogel, S. 1998b. "Remarkable Nectaries: Structure, Ecology, Organophyletic Perspectives III. Nectar Ducts." Flora 193 (2): 113-131. doi:10.1016/S0367-2530(17)30827-7.

Vogel, S. 1998c. "Remarkable Nectaries: Structure, Ecology, Organophyletic Perspectives IV. Miscellaneous Cases." Flora 193 (3):225-248. doi:10.1016/S0367-2530(17)308447.

Weber, M. G., and K. H. Keeler. 2013. “The Phylogenetic Distribution of Extrafloral Nectaries in Plants." Annals of Botany 111 (6): 1251-1261. doi:10.1093/aob/mcs225.

Wergin, W. P., C. D. Elmore, B. W. Hanny, and B. F. Ingber. 1975. "Ultrastructure of the Subglandular Cells from the Foliar Nectaries of Cotton in Relation to the Distribution of Plasmodesmata and the Symplastic Transport of Nectar." American Journal of Botany 62: 842-849.

Weryszko-Chmielewska, E., M. Chwil, and M. Michonska. 2007. "Micromorphology of Nectaries of Rhododendron catawbiense Michx. at Different Flower Development Stages." Acta Agrobotanica 60 (2): 15-22. doi:10.5586/ aa.2007.025

Wykes, G. R. 1952. "An Investigation of the Sugars Present in the Nectar of Flowers of Various Species." New Phytologist 51 (2): 210-215. doi:10.1111/j.1469-8137.1952. tb06127.x.

Zer, H., and A. Fahn. 1992. "Floral Nectaries of Rosmarinus officinalis L. Structure, Ultrastructure and Nectar Secretion." Annals of Botany 70 (5): 391-397. doi:10.1093/ oxfordjournals.aob.a088493.

Zhu, Y. R., M. Yang, J. C. Vamosi, W. S. Armbruster, T. Wan, and Y. B. Gong. 2017. "Feeding the Enemy: Loss of Nectar and Nectaries to Herbivores Reduces Tepal Damage and Increases Pollinator Attraction in Iris bulleyana." Biology Letters 13 (8): 20170271. doi:10.1098/rsbl.2017.0271.

Zimmerman, M. 1988. "Nectar Production, Flowering Phenology, and Strategies for Pollination." In Plant Reproductive Ecology: Patterns and Strategies, edited by J. L. Doust and L. L. Doust, 157-178. New York: Oxford University Press.

Zini, L. M., S. M. Solís, and M. S. Ferrucci. 2014. "Anatomical and Developmental Studies on Floral Nectaries in Cardiospermum Species: An Approach to the Evolutionary Trend in Paullinieae." Plant Systematics and Evolution 300 (6): 1515-1523. doi:10.1007/s00606-013-0978-4. 